\title{
"Study On Risk Factors And Pregnancy Outcome In Pre-Eclamptic Patients: A Study in Sir Salimullah Medical College \& Mitford Hospital, Dhaka, Bangladesh"
}

\author{
Ayesha Siddiquea $^{1 *}$, Abeda Sultana ${ }^{2}$, Shah Mohammad Hassanur Rahman ${ }^{3}$, Most Farjana Islam ${ }^{4}$ \\ ${ }^{1}$ Junior Consultant (Obs \& Gynae), Sreepur Upazila Health Complex, Sreepur, Gazipur, Bangladesh \\ ${ }^{2}$ Junior Consultant (Obs \& Gynae), Palash Upazila Health Complex, Narshingdi, Bangladesh \\ ${ }^{3}$ Junior Consultant (Obs \& Gynae), Pakundia Upazila Health Complex, Pakundia, Kishoreganj, Bangladesh \\ ${ }^{4} J u n i o r$ Consultant (Obs \& Gynae), Dhaka medical College Hospital, Dhaka, Bangladesh
}

\begin{tabular}{ll}
\hline DOI: $10.36348 /$ sjmps.2020.v06i02.015 & | Received: 03.02.2020 | Accepted: 17.02.2020 | Published: 29.02 .2020
\end{tabular}

Abstract

Introduction: Pre-eclampsia is one of the common complications of pregnancy and contributes significantly to high maternal and perinatal morbidity and mortality, especially in developing countries like Bangladesh. Objective: The aim of this study is to identify the risk factors and maternal and foetal outcomes of pre-eclampsia patients. Methods and Materials: This descriptive and observational study with data from the Department of Obstetrics and Gynaecology in Sir Salimullah Medical College and Mitford Hospital, Dhaka, during July 2011 to December 2011. Participants 123 pregnant women with pre-eclampsia included in the study. Main outcome measures Identify the risk factors associated with maternal \& fetal complications, maternal and perinatal mortality \& morbidity and incidence of pre-eclampsia. The patient with particular reference to age, parity, religion, occupation socioeconomic condition, gestational age, rapid weight gain, family history of hypertension and pre-eclampsia, obesity, new paternity, preexisting vascular disease, thrombophilias, previous history of pre-eclampsia, blurring of vision, pain in epigastrium, or pain in right upper quadrant, diabetes mellitus etc. Results: The incidence of pre-eclampsia is $4.3 \%$ and majority of the patients was found to be of $3 \mathrm{rd}$ decade. More than a half $(51.2 \%)$ two third of the patient were primigravida. Maximum $(65.9 \%)$ number was found in the gestational age group of 37 to 40 weeks. Lower abdominal pain $15.4 \%$, Swelling of legs $15.4 \%$, Headache $11.4 \%$, less foetal movement $9.76 \%$ and Blurring of vision $8.13 \%$. Mild pre-eclampsia was $44.0 \%$ and severe pre-eclampsia $56.0 \%$. Fundal height had corresponded with 29 to 34 weeks in $42.0 \%$ patients, presentation was cephalic in $84.0 \%$, fetal heart sounds was audible in $87.8 \%$ cases. The mean systolic and diastolic blood pressure was $164.76 \pm 9.34 \mathrm{mmHg}$ and 101 , $83 \pm 8.64 \mathrm{mmHg}$ respectively and all patients had cephalic presentation. Fresh still birth was 3.5\%, macerated still birth $1.8 \%$, and Prematurity and IUGR were $7.0 \%$. More than one third $(36.4 \%)$ was low birth weight and male of female ratio of the babies were 1.1:1. According to APGAR score $>7$, were 51.5\% and $81.8 \%$ during 1 st and 5th minutes after birth respectively and $16.2 \%$ babies received neonatal resuscitation. Conclusion: Pre-eclampsia usually occurs in third trimester, and maternal outcome is better than fetal outcome although the maternal response to the treatment is in positive side.

Keywords: Preeclampsia, proteinuria, diabetes mellitus, gestational diabetes, risk factors for PE.

Copyright @ 2020: This is an open-access article distributed under the terms of the Creative Commons Attribution license which permits unrestricted use, distribution, and reproduction in any medium for non-commercial use (NonCommercial, or CC-BY-NC) provided the original author and source are credited.

\section{INTRODUCTION}

Pre-eclampsia are a common disorder of pregnancy and a major cause of maternal, fetai and neonatal mortality and morbidity [1]. In Bangladesh the maternal mortality rate is unexpectedly high, i.e. $1.94 / 1000$ live births, among the developing countries [2]. Pre-eclampsia is a multisystem pregnancy induced disorder. The exact etiology of preeclampsia is still unknown, however, many studies have demonstrated that preeclampsia is associated with failure of trophoblastic invasion of the maternal spiral arteries, leading to increased vascular resistance of the uterine arteries and decreased uteroplacental blood flow [3]. Hypertension is a primary sign of the underlying disorder, most often developing after 20 weeks of gestation flow [3]. Hypertension occurs in $7 \%$ to $9 \%$ of all pregnancies. Pre-eclampsia accounts for about $80 \%$ of these cases [4]. Chronic hypertension occurs in approximately $4 \%$ to $5 \%$ of pregnancies with $21 \%$ of these women developing superimposed pre-eclampsia 
[5]. Each year worldwide close to 6, 00000 women die due to complications of pregnancy and child birth. More than $99 \%$ of these deaths occur in developing countries. And two-thirds of these deaths occur in India, Pakistan and Bangladesh. It has been estimated by World Health Organization (WHO) that worldwide approximately 60,000 women die each year from preeclampsia [5, 2]. Development of hypertension and proteinuria in a previously normotensive patient after 20 weeks of gestation is called preeclampsia [6]. Sometimes pre-eclampsia can develop before 20 weeks of gestation, when there are excessive hydatidiform changes in the chorionic villi [4]. Hypertension in pregnancy is defined as diastolic blood pressure of $90 \mathrm{mmHg}$ or more or systolic blood pressure of 140 $\mathrm{mmHg}$ or more after 20 wks of gestation, in women with previously normal blood pressur [6]. An increase in blood pressure by $30 / 15 \mathrm{mmHg}$ over first trimester value is a controversial indicator. Proteinuria is defined as the excretion of SOQmg or more protein in a 24 hours specimen or $30 \mathrm{mg} / \mathrm{dl}$ in a random specimen of urine [7]. Pre-eciampsia occurs in $3 \%-14 \%$ of all pregnancies worldwide [7]. The incidence of Preecampsia in hospital statistics varies widely from $5 \%$ to $15 \%$.Pre-eclampsia occurs in about $6 \%$ of general population; the incidence varies with geographical location [8]. Predisposing factors are nulliparity, black race, maternal age below 20 or over 35 years, low socio-economic status, multiple gestation, hydatidiform mole, polyhydramnions, non-immune fetal hydrops, twin pregnancy, obesity, diabetes, chronic hypertension and underlying renal disease [8, 9]. Pre-eclampsia is associated with increased mortality and morbidity of both mother and baby [10-12, 1]. Preeclampsia is not a totally preventable disease [3], but it resolves completely in post-partum period in most of the cases. Despite a steady reduction in mortality from this disorder in more developed countries, it remains one of the most common causes of maternal death in developing countries. The disorder starts with a placental trigger followed by a maternal systemic response. Because both this systemic response and the women's reaction to it are inconsistent, the clinical presentation varies in time and substance, with many different organ systems affected. With the increasing understanding of the disease process, there have been advances in management, such as anti-hypertensive therapy and use of magnesium sulphate [13]. Proteinuria is extremely valuable as a prognostic sign in pre-eclampsia. Frequent monitoring of the amount of protein excreted in the urine must be a part of the evaluation of these patients. A significant increase in proteinuria indicates that the disease has worsened [6]. Early detection of risk factors of pre-eclampsia and ensuring proper antenatal care allow early diagnosis of pre-eclampsia (Broughton 2001). Careful treatment and monitoring of maternal and foetal condition will reduce maternal and foetal mortality and morbidity from preclampsia $[10,14]$.

\section{OBJECTIVES OF THE STUDY General Objective}

- To identify the risk factors and maternal and foetal outcomes of pre-eclampsia among patients admitted in the Department of Obs and Gynae in Sir Salimullah Medical College and Mitford Hospital, Dhaka.

\section{Specific Objectives}

- To determine the incidence of admitted cases of pre-eciampsia in SSMC and $\mathrm{MH}$

- To explore the risk factors of pre-eciampsia.

- To determine the maternal and foetal complications of pre-eclampsia.

- To evaluate the recent treatment modalities of preeclampsia.

- To identify the avoidable factors responsible for complications of pre-eclampsia to reduce mortality from pre-eclampsia.

\section{Materials ANd Methods}

This descriptive and observational study with data from the Department of Obstetrics and Gynaecology in Sir Salimullah Medical College and Mitford Hospital, Dhaka, during July 2011 to December 2011. Participants: 123 pregnant women with preeclampsia included in the study. Main outcome measures Identify the risk factors associated with maternal \& fetal complications, maternal and perinatal mortality \& morbidity and incidence of pre-eclampsia.

\section{Inclusion criteria}

- Patients with blood pressure $140 / 90 \mathrm{~mm} \mathrm{Hg}$ or more with proteinuria after 20 weeks of gestation.

- Chronic hypertension with superimposed preeciampsia.

\section{Exclusion criteria}

- Patients with blood pressure $140 / 90 \mathrm{~mm} \mathrm{Hg}$ or more with no protein in urine.

- Pregnancy less than 20 weeks.

- Chronic renal diseases.

All patients who will fulfill the inclusion criteria were selected for this study. All data was collected by a pre-structured questionnaire. Patients were selected from those who were admitted in the department of Obs and Gynae of SSMC and MH during the study period. Informed written consent was taken from every patient. After discussion about the purpose and procedure of the study a detailed history was taken from the patient with particular reference to age, parity, religion, occupation socioeconomic condition, gestational age, rapid weight gain, family history of hypertension and pre-eclampsia, obesity, new paternity, preexisting vascular disease, thrombophilias, previous history of pre-eclampsia, blurring of vision, pain in epigastrium, or pain in right upper quadrant, diabetes 
mellitus etc. Thereafter a complete general examination particularly appearance, blood pressure, odema, feature of severe pre-eclampsia and relevant systemic examinations was carried out carefully. Urinary protein and others laboratory investigations like haematocrit level, serum uric acid, lactate dehydrogenase, serum creatinine, blood urea, coagulation profile, ophthalmoscopic examination was done. Previous checkup reports will also be evaluated to find out any clues in favour of risk factors or diagnosis. Based on history, clinical examinations and investigations report proper treatment was provided. Lastly the incidence, risk factors and outcome was recorded in predesigned data collection sheet.

\section{Data Collection and Analysis}

The incidence, risk factors and outcome was recorded in tabulated form and analysed by statistical method. All the information was recorded in a predesigned data collection sheet. The outcomes was analysed with SPSS 16.0. Univariate and-multivariable analyses were used to evaluate the common problems encountered in pre-eclampsia to take appropriate measures to reduce the morbidity and mortality during this period. Pless than 0.05 was consider statistically significant.

\section{ObServations And Results}

During the study period, a total of 5347 pregnant women were admitted. Among them, 231 pregnant mothers presented with pre-eclampsia. So the hospital incidence of pce-eclampsia was $4.3 \%$. Out of 231 pre-eclamptic patients, 123 were enrolled for this study [Table-1].

Table-I: Hospital incidence of pre-eclampsia $(n=231)$

\begin{tabular}{|c|c|c|}
\hline $\begin{array}{c}\text { Total number of obstetric } \\
\text { patients }\end{array}$ & $\begin{array}{c}\text { Total number of pre- } \\
\text { eclamptic patients }\end{array}$ & Percentage \\
\hline 5347 & 231 & 4.3 \\
\hline
\end{tabular}

Table-2: Age distribution of pre eclamptic patients $(n=123)$

\begin{tabular}{|l|c|c|}
\hline \multicolumn{1}{|c|}{ Age (in years) } & Number of patient & Percentage \\
\hline$<20$ & 39 & 31.7 \\
\hline $21-25$ & 36 & 29.3 \\
\hline $26-30$ & 33 & 26.8 \\
\hline $31-35$ & 15 & 12.2 \\
\hline Mean \pm SD & & $24.83 \pm 5,01$ \\
\hline Range (min-max) & $(18-35)$ \\
\hline
\end{tabular}

The above [Table-2] shows the incidence of preeclampsia in different age groups of study population. Majority that is $39(31.7 \%)$ of pre-eclamptic patients were found in the age group of ${ }^{\wedge} 20$ years. The mean age was $24.83 \pm 5.01$ years with range from 18 to 35 years.

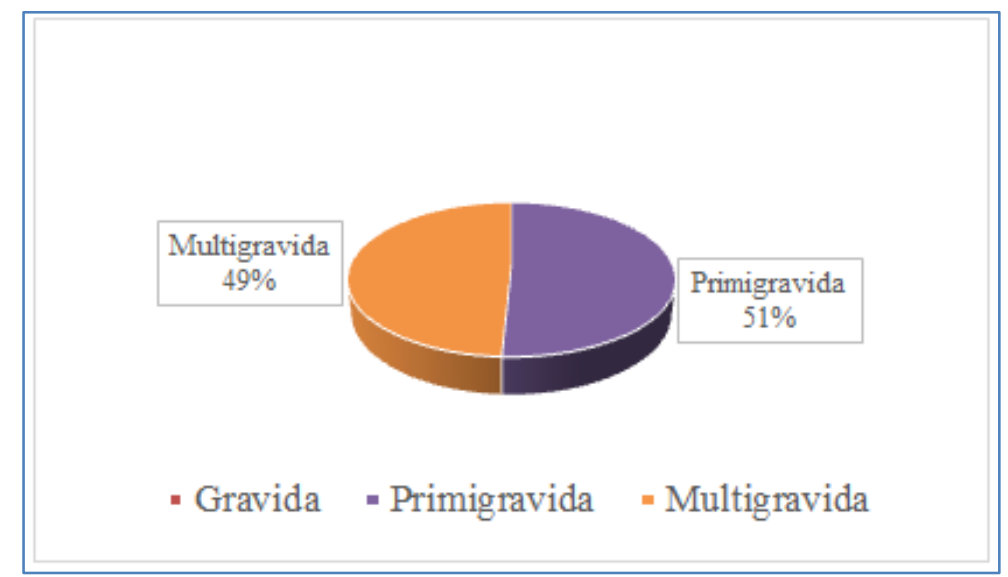

Fig-1: Parity and gravida of study population $(n=123)$ [Figure-1].

It was found that more than half of patients $(51.2 \%)$ were primigravida and $(48.8 \%)$ were multigravid patients 
Table-3: Gestationsl age among study patients $(n=123)$

Gestational age (week) Number of patients Percentage

\begin{tabular}{|l|l|c|}
\hline$<37$ & 42 & 34.1 \\
$>37$ & 81 & 65.9 \\
\hline Mean \pm SD & \multicolumn{2}{|c|}{$37.2 \pm 5.64$} \\
Range (min-max) & \multicolumn{2}{c|}{$(35-40)$} \\
\hline
\end{tabular}

The above [Table-3] shows the gestational age of the study patients. Maximum gestational age was found $81(65.9 \%)$ in $>37$ weeks. The mean gestational age was found $37.2 \pm 5.64$ with range from 35 to 40 weeks.

Table-4: Chief complaints of the patients $(n=123)$

\begin{tabular}{|l|c|c|}
\hline Complaints & Number of patients & Percentage \\
\hline Headache & 14 & 11.4 \\
\hline No Fetal movement & 2 & 1.63 \\
\hline Lower abdominal pain & 19 & 15.4 \\
\hline Less foetal movement & 12 & 9.76 \\
\hline Blurring of vision & 10 & 8.13 \\
\hline Swelling of legs & 19 & 15.4 \\
\hline Vomiting & 4 & 3.25 \\
\hline PA/ watery discharge & 7 & 5.69 \\
\hline Swelling of vulva & 5 & 4.07 \\
\hline PA/ bleeding & 4 & 3.25 \\
\hline Swelling of face & 9 & 7.32 \\
\hline Pallor & 6 & 4.88 \\
\hline Sevre epigastric pain & 6 & 4.88 \\
\hline General weakness & 3 & 2.44 \\
\hline Respiratory distress & 3 & 2.44 \\
\hline
\end{tabular}

Among the studied patients highest percentage had complaints of swelling of legs and lower abdominal pain $19(15.4 \%)$. Next complains were headache 14
$(11.4 \%)$ and then it was less foetal movement 12 $(9.76 \%)$. Other results are depicted in the [Table-4].

Table-5: Classification according to severity of the disease $(n=123)$

\begin{tabular}{|l|c|c|}
\hline Severity of pre-eclamptic & Number of patients & Percentage \\
\hline Mild & 54 & 44.0 \\
\hline Severe & 69 & 56.0 \\
\hline
\end{tabular}

It was found that $54(44.0 \%)$ of the studied patients had mild pre-eclampsia and $69(56.0 \%) \mathrm{DF}$ them had severe pre-eclampsia [Table-5].

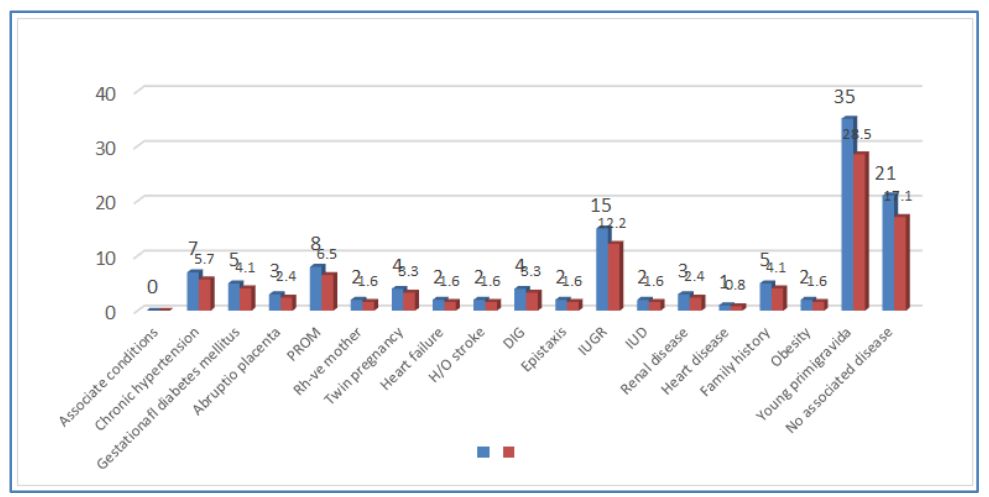

Fig-2: Distribution of associated of clinical conditions $(n=123)$

Out of total 123 preclamptic patients, 21 $(17.1 \%)$ had no associated clinical conditions. 7 (5.7\%) had chronic hypertension, $5(4.1 \%)$ had gestational diabetes mellitus, $8(6.5 \%)$ had PROM, $15(12.2 \%)$ had
IUGR, $3(2.4 \%)$ abruptio placenta, 2 (1.6\%) had IUD, 5 $(4.1 \%)$ had family history, $35(28.5 \%)$ young primigravida associated with pre-eclampsia [Figure-2]. 
Table-6: Per abdominal findings of the patients $(n=123)$

\begin{tabular}{|c|c|c|}
\hline \multirow{2}{*}{\begin{tabular}{|l|} 
Parameters \\
Fundal height (weeks)
\end{tabular}} & Number of patients & \multirow[t]{2}{*}{ Percentage } \\
\hline & & \\
\hline $20-28$ weeks & 39 & 32.0 \\
\hline $29-34$ & 52 & 42.0 \\
\hline $35-40$ & 32 & 26.0 \\
\hline \multicolumn{3}{|l|}{ Lie } \\
\hline \multirow{3}{*}{$\begin{array}{l}\text { Longitudinal } \\
\text { Transverse } \\
\text { Others }\end{array}$} & 120 & 97.6 \\
\hline & 2 & 1.6 \\
\hline & 1 & 0.8 \\
\hline \multicolumn{3}{|l|}{ Presentation } \\
\hline \multirow{2}{*}{$\begin{array}{l}\text { Cephalic } \\
\text { Breech }\end{array}$} & 103 & 84.0 \\
\hline & 20 & 16.0 \\
\hline \multicolumn{3}{|l|}{ Foetal heart sound } \\
\hline Present & 108 & 87.8 \\
\hline Absent & 2 & 1.6 \\
\hline
\end{tabular}

Per abdominal examination revealed that, 52 (42.0\%) patient's fundal height had corresponded with 29 to 34 weeks. Presentation was cephalic in 103
$(84.0 \%)$, fetal heart sounds was audible in $108(87.8 \%)$ cases [Table-6].

Table-7: Mean of systolic and mean of diastolic blood pressure of the patients $(n=123)$

\begin{tabular}{|l|c|c|}
\hline Blood pressure (mmHg) & Mean \pm SD & Range (min-max) \\
\hline $\begin{array}{l}\text { Systolic bio9d pressure Diastolic blood } \\
\text { pressure }\end{array}$ & $164.76 \pm 9.34101 .83 \pm 8.64$ & $(140-200)$ \\
& & $90-120)$ \\
\hline
\end{tabular}

The mean systolic blood pressure was $164.76+9.34 \mathrm{mmHg}$ with range from 140 to 200 $\mathrm{mmHg}$. The mean diastolic blood pressure was
$101.83+8.64 \mathrm{mmHg}$ with range from 90 to $120 \mathrm{mmHg}$ [Table-7].

Table-8: Distribution of assessment of fetal movement and amniotic fluid volume $(n=123)$

\begin{tabular}{|c|c|c|}
\hline Per abdominal examination & Number of patients & Percentage \\
\hline Volume of the amniotic fluid \\
Seems to be adequate \\
$\begin{array}{c}\text { Seem to be less (mild) } \\
\text { Seems to be less (severe) }\end{array}$ & 39 & \\
\cline { 2 - 3 } \begin{tabular}{c} 
Seems to be more \\
\cline { 2 - 3 }
\end{tabular} & 42 & 39.4 \\
\cline { 2 - 3 } & 12 & 42.4 \\
\hline Foetal movement \\
$\begin{array}{c}\text { Present } \\
\text { Less } \\
\text { Absent }\end{array}$ & 6 & 12.1 \\
\cline { 2 - 3 } & 109 & 6.1 \\
\cline { 2 - 3 } & 12 & 9.8 \\
\hline \multirow{2}{*}{} & 2 & 1.6 \\
\hline
\end{tabular}

The above [Table-8] shows that, most of the patients had amniotic fluid volume seem to be less (mild) $42(42.4 \%)$. In the foetal movement, present was found in $109(88.6 \%)$ and less in $12(9.8 \%)$ patients.

Table-9: Results of bedside heat coagulation test of urine among these patients $(n=123)$

\begin{tabular}{|l|c|c|}
\hline Heat coagulation test & Number of patients & Percentage \\
\hline+ & 27 & 22.0 \\
\hline++ & 51 & 41.5 \\
\hline+++ & 36 & 29.3 \\
\hline++++ & 9 & 7.3 \\
\hline
\end{tabular}

The above [Table-9] shows that all of the patients had proteinuria. It was "+" in $27(22.0 \%)$ case and was"++++" in $9(7.3 \%)$ cases. 
Table-10: Important biochemical findings in the study population $(n=123)$

\begin{tabular}{|r|c|c|}
\hline Parameters & Number of patients & Percentage \\
\hline Blood Urea & & \\
$<20 \mathrm{mg} / \mathrm{dl}$ & & 78.0 \\
\cline { 2 - 3 }$>20 \mathrm{mg} / \mathrm{dl}$ & 27 & 22.0 \\
\cline { 2 - 3 } & & \\
\hline $\begin{array}{c}\text { Serum creatinine } \\
<0.8 \mathrm{mg} / \mathrm{dl}\end{array}$ & 84 & 68.0 \\
\cline { 2 - 3 }$>0.8 \mathrm{mg} / \mathrm{d} !$ & 39 & 32.0 \\
\hline $\begin{array}{r}\text { Serum uric acid } \\
<6 \mathrm{mg} / \mathrm{dl} \\
>6 \mathrm{mg} / \mathrm{di}\end{array}$ & 69 & 56.0 \\
\cline { 2 - 3 } & 54 & 44.0 \\
\hline
\end{tabular}

The above [Table-10] shows that $27(22.0 \%)$ had blood urea level $>20 \mathrm{mg} / \mathrm{dl}, 39(32.0 \%)$ patients had serum creatinine level $£ 0.8 \mathrm{mg} / \mathrm{dl}$ and $54(44.0 \%)$ had serum uric acid level $>6 \mathrm{mg} / \mathrm{dl}$.

Table-11: Number $(\%)$ of the patients received magnesium sulphate $(n=123)$

\begin{tabular}{|l|c|c|}
\hline Magnesium sulphate & Number of patients & Percentage \\
\hline Yes & 96 & 78.0 \\
\hline No & 27 & 22.0 \\
\hline
\end{tabular}

The above [Table-11] shows that $96(78.0 \%)$ patients received magnesium sulphate.

Table-12: Mode of termination of pregnancy/mode of delivery of study population $(n=123)$

\begin{tabular}{|l|c|c|}
\hline Mode of delivery & Number of patients & Percentage \\
\hline LUCS & 76 & 62.0 \\
\hline Vaginal delivery & 37 & 30.0 \\
\hline Spontaneous Abortion & 10 & 8.0 \\
\hline
\end{tabular}

It was found that out of $\mathrm{t} 23$ patients, 76

$(62.0 \%)$ delivered by lower uterine caesarian section,
$37(30.0 \%)$ patients delivered by vaginal delivery, 10 $(8.0 \%)$ had spontaneous abortion [Table-12].

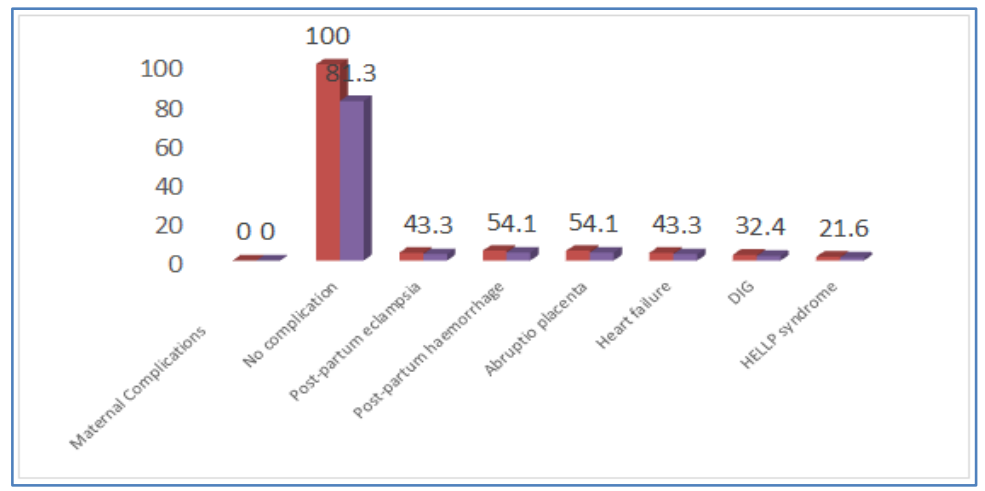

Fig-3: Incidence of maternal complications $(n=123)$

It was found that out of 123 patients 100 $(81.3 \%)$ had no complication following delivery, 4 $(3.3 \%)$ had post-partum eclampsia, $5(4.1 \%)$ had post- partum haemorrhage, $5(4.1 \%)$ had abruption placenta, $4(3.3 \%)$ had heart failure, $3(2.4 \%)$ had DIG and 2 $(1.6 \%)$ had HELLP syndrome [Figure-3].

Table-13: Maternal outcome of the study population $(n=123)$

\begin{tabular}{|l|c|l|}
\hline Maternal outcome & $\begin{array}{l}\text { Number of } \\
\text { patients }\end{array}$ & $\begin{array}{l}\text { Percentag } \\
\text { e }\end{array}$ \\
\hline Clinical improvement after delivery & 103 & 83.7 \\
\hline PPH & 5 & 4.1 \\
\hline Post-partum eclampsia & 4 & 3.3 \\
\hline HELLP syndrome & 2 & 1.6 \\
\hline DIG & 3 & 2.4 \\
\hline Heart failure & 4 & 3.3 \\
\hline
\end{tabular}


The above [Table-13] shows the maternal outcome of the study populatios. Clinical improvement were found in $103(83.7 \%), 5(4.1 \%) \mathrm{PPH}, 4(3.3 \%)$ post-partum eclampsia, 2 (1.6\%) HELLP syndrome, 3 $(2.4 \%)$ DIG and $4(3.3 \%)$ heart failure.

Table-14: Foetal outcome of the pre eclamptic patients $(n=113)$

\begin{tabular}{|l|c|c|}
\hline Parameters & Number of patients & Percentage \\
\hline Live birth & 99 & 87.6 \\
\hline Fresh still birth & 4 & 3.5 \\
\hline Macerated still birth & 2 & 1.8 \\
\hline Prematurity & 4 & 3.5 \\
\hline IUGR & 4 & 3.5 \\
\hline
\end{tabular}

Above [Table-14] shows that preeclamptic mothers delivered live born fetuses 99 (87.6\%), fresh still birth was $4(3.5 \%)$, macerated still birth $2(1.8 \%)$ and Prematurity and IUGR were $8(7.0 \%)$.

Table-15: Distribution of the parameter of foetal weight and foetal sex $(n=99)$

\begin{tabular}{|l|c|c|}
\hline Foetal outcome & $\begin{array}{c}\text { Number of } \\
\text { patients }\end{array}$ & Percentage \\
\hline Weight (Kg) & & \\
\hline Extremely low birth weight (ELBW) & 3 & 3.0 \\
\hline Very low birth weight (VLBW) & 6 & 6.1 \\
\hline Low birth weight (LBW) & 27 & 27.3 \\
\hline Normal birth weight & 63 & 63.6 \\
\hline Sex & & 51.4 \\
Male & 57 & 48.6 \\
\cline { 2 - 3 }
\end{tabular}

Extremely low birth weight (ELBW) means foetal weight is < 1000 grams or 2.2 Ibs Very low birth weight (VLBW) means foetal weight is $<1500$ grams or 3.3 Ibs Low birth weight (LBW) means foetal weight is $<2500$ grams or 5.5 Ibs. Normal birth weight means foetal weight is > 2500 grams or 5.5 Ibs. Maximum babies $63(63.6 \%)$ were of normal birth weight, $3 \%$ of babies had extremely low birth weight, $6.1 \%$ had very low birth weight and $27.3 \%$ were of low birth weight. Male of female ratio of the babies were 1.1:1 [Table$15]$

Table-16: Distribution of APGAR score of the newborn babies ( $n=99)$

\begin{tabular}{|c|c|c|}
\hline APGAR score (minute) & $\begin{array}{l}\text { Number of } \\
\text { patients }\end{array}$ & Percentage \\
\hline $\begin{array}{c}\text { After 1 minute } \\
1-3\end{array}$ & 3 & \\
\cline { 2 - 3 } $2-6$ & 45 & 3.0 \\
\cline { 2 - 3 } 27 & 51 & 45.5 \\
\cline { 2 - 3 } & & 51.5 \\
\hline After 5 minute & 12 & 12.1 \\
\cline { 2 - 3 } $4-3$ & 6 & 6.1 \\
\cline { 2 - 3 }$>7$ & 81 & 81.8 \\
\hline
\end{tabular}

Above [Table-16] shows that majority of the newborn babies had APGAR score after 1 minute $>7$, which was $51(51.5 \%)$. After 5 minutes APGAR score $>7$, which was observed in $81(81.8 \%)$. 


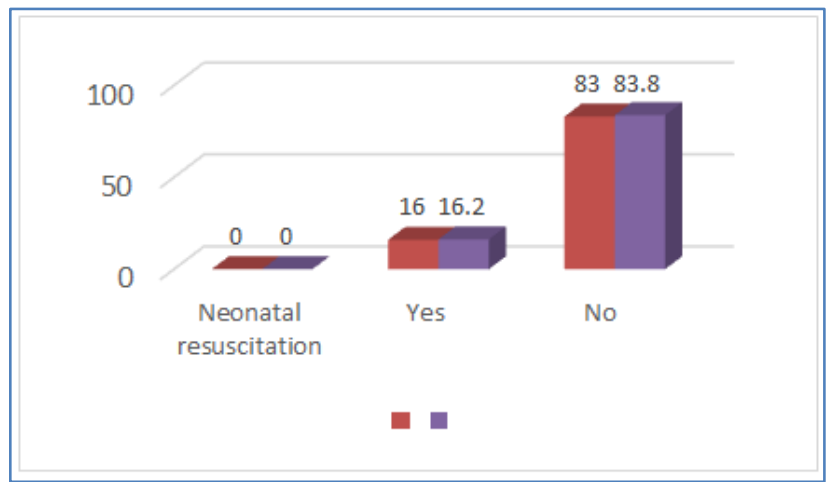

Fig-4: Babies needed neonatal resuscitation $(n=99)$

The above table shows the number of percentage of babies received neonatal resuscitation was $16(16.2 \%)$ [Figure-4]

\section{DISCUSSION}

This descriptive and observational study was carried out with an aim to identify the risk factors and maternal and foetal outcomes of pre-eclampsia arflong patients as well as the incidence of pre-eclampsia; explore the risk factors of pre-eclampsia with maternal and foetal morbidity and mortality. A total of 123 pregnant women with pre-eclampsia 35 to 40 weeks of gestation were included in the study who were admitted in the Department of Obstetrics and Gynaecology in Sir Salimullah Medical College and Mitford Hospital, Dhaka, during July 2011 to December 2011. The present study findings were discussed and compared with previously published relevant studies. In this current study, a total of 5347 obstetrics cases were admitted in the above mentioned hospital during the study period, out of which 231 cases were prelampsia, therefore, the incidence of preeclampsia is $4.3 \%$. The global incidence of preeclampsia has been estimated at $5-14 \%$ of all pregnancies. In developing nations, the incidence of the disease is reported to be $4-18 \%$ [15]. Worldwide, the incidence of preeclampsia ranges between $2 \%$ and $10 \%$ of pregnancies. The incidence of preeclampsia, the precursor to eclampsia, varies greatly worldwide. WHO estimates the incidence of preeclampsia to be seven times higher in developing countries $(2.8 \%$ of live births) than in developed countries $0.4 \%$ [16]. The incidence of eclampsia in the developed countries of North America and Europe is similar and estimated to be about 5-7 cases per 10,000 deliveries. Vatten and Skjaerven, mentioned in their study that the incidence of preeclampsia in the United States is estimated to range from $2 \%$ to $6 \%$ in healthy, nulliparous women [17]. On the other hand, incidence of eclampsia in developing nations varies widely, ranging from 1 case per 100 pregnancies to 1 case per 1700 pregnancies [18]. Rates from African countries such as South Africa, Egypt, Tanzania, and Ethiopia vary from $1.8 \%$ to $7.1 \%$ [19]. In Nigeria, prevalence ranges between $2 \%$ to $16.7 \%$ [20]. In this study it was observed that the mean age was $24.83+5.01$ years with range from 18 to 35 years and the maximum number was found in the age group of $<20$ years. In this current study it was observed that the studied patients highest percentage had complaints of swelling of legs and lower abdominal pain $15.4 \%$ followed by headach'e $11.4 \%$, less foetal movement $9.76 \%$, Blurring of vision $8.13 \%$, swelling of face $7.32 \%$, PA/ watery discharge $5.69 \%$ and Pallor, Severe epigastric pain, swelling of vulva, vomiting, PA/ bleeding, genera, weakness, respiratory distress, no fetal movement varied from $1.0 \%$ to $5.0 \%$. Regarding the associated clinical conditions and risk factors in this current study, it was observed that $12.2 \%$ IUGR, 6.5\% PROM, 5.7\% chronic hypertension, $4.1 \%$ gestational diabetes mellitus, Twin pregnancy/DIC $3.3 \%$ and abruptio placenta, renal disease, rh-ve mother, heart failure, $\mathrm{H} / \mathrm{O}$ stroke Epistaxis, IUD, family history $5(4.1 \%)$, obesity $2(1.6 \%)$, young primigravida $35(28.5 \%)$ heart disease were within $2.5 \%$. Holzgreve et al. mentioned that maternal fetal cell trafficking is significantly disturbed in pregnancies complicated by preeclampsia, with elevated numbers of fetal cells detected in the maternal circulation during these pregnancies [21]. Similarly, Yie et al. found almost $50.0 \%$ patients had mild preeclampsia and $50.0 \%$ had severe pre-eclampsia, which is comparable with the current study [22]. On the other hand [23], showed $60.8 \%$ mild pre-eclampsia and $39.2 \%$ severe pre-eclampsia. Severe pre-eclampsia was comparatively higher in the current study, which may due to the lack of knowledge about pre-eclampsia in our study patients. Per abdominal examination revealed in this current study those $42.0 \%$ patients fundal height had corresponded with 29 to 34 weeks, presentation was cephalic in $84.0 \%$ and fetal heart sounds was audible in $87.8 \%$ cases. In this present study it was observed that the systolic blood pressure varied from 140 to $200 \mathrm{mmHg}$ and diastolic blood pressure 90 to $120 \mathrm{mmHg}$. The mean systolic blood pressure was $164.76 \pm 9.34 \mathrm{mmHg}$ and diastolic blood pressure $101.83 \pm 8.64 \mathrm{mmHg}$. Maximum patients had high systolic and diastolic blood pressure. Similar observations regarding the blood pressure were also made by [24]. Hall and Odendal, had observed the mean systolic and diastoiic blood pressure were 154+16 $\mathrm{mmHg}$ and $101 \pm 8 \mathrm{mmHg}$ respectively, which support 
the current study [25]. In this present series it was 'observed that $22.0 \%$ showed levels of proteinuria + , 41.5 percent ++ and 29.3 percent +++ and 7.3 percent Blood urea level $>20 \mathrm{mg} / \mathrm{dl}$ was in $22.0 \%$, serum creatinine level $£ 0.8 \mathrm{mg} / \mathrm{dl}$ in $32.0 \%$, serum uric acid level $>6 \mathrm{mg} / \mathrm{dl}$ in $44.0 \%$ and nearly eighty $(78.0 \%)$ percent patients received magnesium sulphate. On the other hand, Gartner et al. observed $57.0 \%$ of the patients were normal vaginal delivery. It was observed in this study that most $(81.3 \%)$ of the patients had no complain, $3.3 \%$ had post-partum eclampsia, $4.1 \%$ had post-partum haemorrhage, $4.1 \%$ had abruption placenta, $3.3 \%$ had Heart failure, $2.4 \%$ had DIG and $1.6 \%$ had HELLP syndrome. Almost similar observations regarding the maternal outcome were made by [25]. It was observed in this study that Clinical improvement were found in $83.7 \%, 4.1 \% \mathrm{PPH}, 3.3 \%$ post-partum eclampsia, $1.6 \%$ HELLP syndrome, $2.4 \%$ DIG and $3.3 \%$ Heart failure. In this series it was observed that more than one third $(36.4 \%)$ babies had low birth weight, out of which $3.0 \%$ of babies were extremely low birth weight, $6.1 \%$ very low birth weight, $27.3 \%$ were of low birth weight and $63.6 \%$ were of normal birth weight [26], observed mean $( \pm \mathrm{SD})$ birth weight was $2.8 \pm 0.8 \mathrm{~kg}$, which is comparable with the current study. In this current study it was observed that male of female ratio was 1.1:1 of the babies were. Hall and Odendai, who had observed in their studies, the APGAR score > 6 found in $94.0 \%$ of the new born during 5th minute after birth [25]. In the present study it was observed that APGAR score $>7$ were $51.5 \%$ and $81.8 \%$ at 1 st and 5 th minutes after birth respectively. The results of the current study are comparable with the above mentioned study. In this study it was observed that $16.2 \%$ babies received neonatal resuscitation.

\section{CONCLUSION}

This study was undertaken to identify the risk factors and maternal and foetal outcomes of preeciampsia patients as well as the incidence of preeclampsia; .explore the risk factors of pre-eclampsia with maternal and foetal morbidity and mortality. A total of 123 pregnant women with pre-eclampsia 35 to 40 weeks of gestation who were admitted in the Department of Obstetrics and Gynaecology in Sir Salimullah Medical College and Mitford Hospital, Dhaka, during July 2011 to December 2011. The incidence of preeclampsia in this study was $4.3 \%$. Maximum women with pre-eclampsia was belongs to 3rd decade. Majority of the patients were primipara and majority of the patients was between 37 to 40 weeks of gestation. Lower abdominal pain, swelling of legs, Headache, Less foetal movement, IUGR, PROM and Chronic hypertension were more common. Premature rupture of membrane, vaginal/perineal tear and impending eclampsia were more common of the study patients and preterm, IUGR, asphyxia are more frequent fetal complications, however neonatal resuscitation and admission in paediatric department needed for some newborn. Maternal outcome is better than fetal outcome although the maternal response to the treatment is in positive side.

\section{REFFERENCE}

1. Hassan, T. J., Sadaruddin, A., \& Jafarey, S. N. (1991). Serum calcium, urea and uric acid levels in pre-eclampsia. J Pak Med Assoc, 41(8), 183-5.

2. BBS. (1999). Bangladesh Bureau-of Statistics, June 1999. Bangladesh at a Glance

3. Dutta, D.C. (2011). Text book of Obstetrics, seventh edition, New Central Book Agency (P) Ltd. Kolkata, 688.

4. Decherney, A.H., Nathan, L. (2004). Current obstetrics and gynecologic diagnosis and treatment. 9th edition, McGraw-Hill companies New York, 338-353.

5. Gillbert, E.S. (2006). Manual of High Risk Pregnancy and Delivery. 4thEdition. Mosby, 744.

6. Arias, P., Daftary, S.N., Bhide, A.G. (2009). Practical guide to high-risk pregnancy and delivery, a south Asian perspective, 3rd edition, Elsevier, New Delhi, 572.

7. Edmonds, O.K. (2007). Dewhurst's Textbook of Obstetrics and Gynaecology. Seventh edition. Blackwell Publishing Inc. Oxford, UK, 717.

8. Nilsson, E., Ros, M.S. (2004). The importance of genetic and environmental effects for preeclampsia and gestational hypertension: a family study. BJOG, 111, 200-206.

9. Kieler, H., Zettergren, T., Svensson, H., Paul, W., Dickmanb, E., Larsson, A. (2003). Assessing urinary albumin excretion in pre-eclamptic women: which sample to use? BJOG: an International Journal of Obstetrics and Gynaecology, 110, 1217.

10. Steer, P., Little, M.P., Elliott, P. (2004). Maternal blood pressure in pregnancy, birth weight and perinatal mortality in first birth: Prospective study. BMJ, 4(329), 1312-1314.

11. Dekker, G., Sibai, B.M. (2001). Primary, Secondary and tertiary prevention of preeclampsia. Lancet, 357, 209-216.

12. Dekker, G.A., Sibai, B.M. (1993). Low dose aspirin in the prevention of pre-eclampsia and fetal growth retardation: rationale, mechanism and clinical trials. Am J Obstet Gynecol, 168, 214-227.

13. Walker, J.J. (2000). Pre-eclampsia. Lancet, 356, 1260-1264.

14. Cotter, A.M., Martin, C.M., O'Leary, J.J., Sean, P. (2004). Increased fetal DNA in the maternal circulation in early pregnancy is associated with an increased risk of preeclampsia. Am J of Obstet Gynecol, 191, 515-520.

15. Ngoc, NT. Merialdi, M., Abdet-Aieem, H., Carroli, G., Purwar, M., Zavaleta, N. (2006). Causes of stillbirths and early neonatal deaths: data from 7993 pregnancies in six developing countries. Bull World Health Organ, 84(9), 699-705. 
16. WHO (2005). Make every mother and child count, in the world health report 2005, World Health Organization, Geneva, Switzerland.

17. Vatten, L.J., Skjaerven, R. (2004). Is pre-eclampsia more than one disease?. BJOG, 111(4), pp.298302.

18. Shah, A.K., 2009. Preeclampsia and Eclampsia, http:// emedicine. medscape.com/article/1184270overview.

19. Kiondo, P., Wamuyu-Maina, G., Bimenya, G. S., Tumwesigye, N. M., Wandabwa, J., Okong, P. (2011). Risk factors for pre-eclampsia in Mulago Hospital, Kampala, Uganda. Tropical Medicine \& International Health, 10, 1365-3156.

20. Olopade, F.E., Lawoyin, T.O. (2008). Maternal mortality in a Nigerian Maternity Hospital. African Journal Biomedical Research, 11(3), 267-273.

21. Holzgreve, W., Ghezzi, F., Di Naro, E., Maymon, E., Ganshirt, D., Hahn, S. (1998). Disturbed fetomaternal cell traffic in preeclampsia. Obstet Gynecol, 91, 669-672.
22. Yie, S.M., Li, L.H., Xiao, R., and Librach, C.L. (2008). A single base-pair mutation in the 30untranslated region of HLA-G mRNA is associated with pre-eclampsia. Molecular Human Reproduction, 14(11), 649-653.

23. Brown, J.S., Buddie, T.J. (1996). Hypertension in pregnancy: maternal and fetal outcomes according to laboratory and clinical features. MJA, 165, 360365.

24. Davidge, ST., Hubel, C.A., Brayden, R.D., Capeien, E.G., Laughlin, M.K. (1992). Sera antioxidant acitivity in uncomplicated \& preeclamptic pregnancies. Obstet \& Gynaecol, 79, 897-901.

25. Hall, D.R., Odendal, J.H. (2002). Urinary protein excretion and expected management of early onset, severe prew-eclampsia. Int J Gynaecol Obset, 77, $1-6$.

26. Niromanesh, S., Laghii, S. (2001). Supplementary calcium in prevention of Pre-eclampsia. Int $J$ Gynaecol Obstet, 74, 17-21. 